\title{
Oil Price Shocks and Stock Markets in Oil Importing Countries: Evidence from Egypt, Morocco, and Jordan
}

\author{
Demeh Daradkah*iD, Josanco Floreani**iD, Stefano Miani $^{* * *}$ iD
}

\begin{abstract}
This study aims to investigate the dynamic relationship between Oil price Shocks and stock markets returns in Egypt, Morocco, and Jordan as oil-importing countries in the MENA region, over the period (2005-2018). Vector auto regressive regressions (VAR), Granger causality tests, and Impulse Response technique are employed to achieve the objectives of the study. Using weekly data, the results point to a causal relation flowing from oil prices to stock market returns in all the three countries under investigation although with different lags and different patterns of the response according to the impulse response function outcomes. These findings have important implications for academics, domestic and international investor, investment manager and policy makers.
\end{abstract}

Keywords: oil price shocks; stock markets returns; Egypt; Morocco; Jordan.

JEL classification: Q41; E44; N15.

\section{INTRODUCTION}

Energy consumption shows an increasing trend through the last decades, where it grew 10 -year average of 1.5 percent per year. Although of different energy mix, oil remains the most dominant source of fuel. In 2018, it represented 33.62\% of sources of fuel, second largest source of fuel is Coal, representing $27.21 \%$, Natural gas represents $23.87 \%$ of source of fuel, followed by Hydro-electricity, Nuclear energy, and Renewables, representing 6.84, 4.41, and 4.05 percent of source of fuel, respectively. Oil consumption increased by 1.4 million barrels per day, despite of increasing oil prices, where it increased $\$ 71.31$ per barrel at the end of 2018. The Middle East consumes $6.51 \%$ of the total world fuel, and $8.84 \%$ of the total world oil (British Petroleum, 2019).

\footnotetext{
* Department of Finance and Banking Science, Faculty of Economics and Administrative Sciences, Yarmouk University, Jordan; e-mail: dima_daradkeh@yahoo.com (corresponding author).

*** Department of Economics and Statistics, University of Udine, Italy; e-mail: josanco.floreani@ uniud.it.

Department of Economics and Statistics, University of Udine, Italy; e-mail: stefanio.miani@uniud.it.
} 
Oil price plays an important role in economic development (Hamilton, 1983). On the other hand, it is affected by either supply forces, which are forced by geopolitical events, or demand forces, which are forced by growth in developing countries (Hamilton and James, 2009). However, oil prices are closely related to stock markets' performance. This critical, complex, and dynamic issue received serious attention from economist, politicians, investors, and policy makers.

A large amount of literature has examined the relationship between oil price and stock market in large industrial countries. Despite of the importance and consumption of the Middle East, a few studies focused on this issue in the Middle East, especially in Egypt, Morocco, and Jordan.

Egypt is a developing country in North Africa, the population in Egypt ranks $13^{\text {th }}$ in the world, where it reached 98,423,595 by the end of 2018. The Egyptian economy is one of the largest in the Middle East with a GDP of \$ 250.90 billion by the end of 2018, in which it represented 0.40 percent of the world economy (World Bank, 2018), and the Egyptian Stock Market (ExSM) is considered one of the oldest stock markets in the world. In addition, Egypt consumed 0.90 percent of the world's total oil consumption (British Petroleum, 2019).

Jordan is an oil-importing and a lower-middle income country with a GDP per capita of USD 4,129.75 by the end of 2018 (World Bank, 2018). However, Jordanian stock market [Amman Stock Exchange (ASE)] is considered as one of the most innovative in the Middle East region. This is due to the liberalization of ASE in 1995 (OECD, 2006). Thus, ASE is considered attractive for foreign investors, where foreign investors have no restrictions on the percentage of ownership, and their stock income (cash dividends and capital gain) is free from tax (International Institute for Labour StudIes, 2013).

Morocco is a developing country in North Africa in which the population reached 36.03 million by the end of 2018. The Moroccan economy represents 0.19 percent of the world economy with a GDP of \$ 117.921 billion by the end of 2018 (World Bank, 2018). This rapid economic growth consequently increases the need for energy. However, oil and gas reserves are considered low in Morocco, therefore, 24\% of Moroccan imports are for energy (International Monetary Fund, 2011). The Moroccan Stock Market [Casablanca Stock Market (MCS)] is considered the third largest of stock markets in Africa.

Therefore, the objective of this study is to highlight Middle East evidence on this issue, by investigating the dynamic relationship between oil price shocks and stock markets in Egypt, Morocco, and Jordan using Vector auto regressive regressions (VAR), Granger causality tests ,and Impulse Response technique over the period (2005-2018), in which this period witnessed a significant conflict in the context of the Global Financial Crisis in 2007-2009, and the political conflict in the Middle East since the beginning of 2011 in which is called "The Arab Spring", and also the civil war in Libya since 2011. Hence, affecting the oil price.

This study consists of five sections following the introduction. Section 2, Literature Review; in which a number of studies related to topic of the study are reviewed. Section 3 describes data and Methodology. Section 4, reports the results of the analysis. Conclusions and Recommendations are stated in Section 5.

\section{LITERATURE REVIEW}

In the early 8o's the influential work of Hamilton (1983), was the starting point that documented the significant relationship between oil price and economic development, where 
he indicated that oil price fluctuation was responsible for US recessions, from the end of World War II to the early 80's. Following Hamilton (1983), a growing body of work indicated the major role of oil price on economic growth (Burbidge and Harrison, 1984; Gisser and Goodwin, 1986).

Almost after a decade, a growing number of studies examine another pattern, and integrating oil price with financial markets. For instance: Brown et al. (1990), Ferson and Harvey (1995), Kaneko and Lee (1995) found a negative relationship between oil price and stock market returns. On the other hand, N. F. Chen et al. (1986), Hamao (1988) and Huang et al. (1996) report no relationship between oil price and stock market returns.

Since then succeeding studies examined the relationship between oil price and stock market returns using different models and techniques at country and global level. For instance, Jones and Kaul (1996) report that oil prices have significant and negative relationship for aggregate stock market returns for US and Canada. Consistently Sadorsky (1999) introduced supporting evidence for US markets over the period (1986 - 1996), and showed a negative relationship between oil price and stock market returns.

In addition, Papapetrou (2001) found a negative relationship between oil price and stock market returns in Greece. On the other hand, for Chinese stock market returns, Cong et al. (2008) documented no relationship between oil price changes and stock market returns. Jammazi and Aloui (2010) inspected the same issue in UK, France, and Japan. They documented no relationship between oil price and stock market returns.

Furthermore, studies were conducted on global market indexes; for example S. S. Chen (2010) and Nandha and Faff (2008) conducted their works on Global Industry Indices, and S\&P Index, respectively. They documented a negative relationship.

However, investigating trends in oil prices are far from being an easy task due to various structural drivers that can jointly impact them. For the same reason, the relationship between oil prices and financial markets, as captured by movements of stock prices, volatilities or interest rates is quite complex. Moreover, most of the existing studies suffer a low-frequency data bias which prevents analysis from delivering a true and updated picture of economic trends.

In an excellent attempt to overcome those biases, Venditti and Veronese (2020) employ a daily structural VAR model to jointly model spot and future oil prices along with stock prices. Their model allows the decomposition of oil prices in three structural shocks, i.e. a forward looking demand shock, an unexpected change in current business conditions and a supply shock with different implications in terms of financial assets' response.

Although, a large amount of literature has examined the relationship between oil prices and stock market returns. It is noted that the impact of oil prices differ between importing and exporting countries (Miller and Ratti, 2009).

The majority of studies suggest a positive relationship between oil price and stock market returns in oil-exporting countries (see: Zarour, 2006; Lescaroux and Mignon, 2008; Park and Ratti, 2008; Bjørnland, 2009; Korhonen and Ledyaeva, 2010; Mendoza and Vera, 2010; M. E. H. Arouri and Rault, 2012; Wang et al., 2013). On the other hand, the majority of studies suggest a negative relationship between oil price and stock market returns in oilimporting countries (see: Jiménez-Rodríguez and Sanchez, 2005; O'Neill et al., 2008; Filis, 2010). Similarly, Youssef and Mokni (2019) and Mokni (2020) document the same results for oil-importing and exporting countries during the period from 1999 -2018.

For Gulf Corporation Council (GCC) countries, M. E. H. Arouri and Rault (2012) documented a short-term linkage between oil prices and stock returns, and a positive 
relationship for stock returns for all GCC countries except for Saudi Arabia. In addition, M. Arouri et al. (2011) studied the relationship between oil price and stock market return over the period 2005-2010 using daily data, and they found a positive relationship in Bahrain, Oman, Qatar. Consistently, Mohanty et al. (2011) documented a positive relationship between oil prices and stock market returns except for Kuwait. Thus, Maghyereh and Al-Kandari (2007) documented a long-term relationship between oil prices and stock market returns.

More recently, Al-Hajj et al. (2018) investigates the dynamic relationship between oil price and aggregate and sectorial stock market return, respectively in Malaysia. They found stock market return is sensitive to oil price.

As for Jordan, Bouri et al. (2016) examined the causality relationship between oil price and sectorial stock market before and after Arab uprisings, and they found different results across sectors, for instance they found no relationship between oil prices and the industrial sector. Thus, Al-Qudah (2014) inspected the relationship between oil price shocks and stock market returns over the period 2000-2014 using monthly data from ASE, and documented a negative significant relationship between oil price shocks and stock market returns, and found no directional causality from oil price shocks to stock returns.

Moreover, Zamereith Gourène and Mendy (2018) studied the co-movement between oil price and stock market returns in six African countries including Egypt and Morocco over the period 2003-2012. They concluded that the co-movement is low in the short and medium term but is relatively strong in the long-term. On the other hand, Abdulkarim et al. (2020) examined the relationship between the change in oil price and stock market volatilities in 5 African Islamic indices (Egypt, Tunisia, Morocco, Nigeria, and South Africa) during the period 2011-2018, in which Tunisian Islamic index is considered the lowest volatility with oil price. Ajmi et al. (2014) examined the relationship between the change in oil price and stock market returns in 11 MENA countries, in which Jordan and Morocco were included. They found that positive changes and negative changes in oil prices affected the stock market returns in Jordan and Morocco, respectively. Consistently, Abdelsalam (2020) found the same results for 17 MENA countries including Egypt, Morocco, and Jordan. However, Al-Fayoumi (2009) examined the relationship between oil price and stock market returns of Turkey, Tunisia, and Jordan as oil-importing countries over the period (1997-2008). They found no relationship between oil price and stock market returns in Jordan.

Overall, it can be concluded that most of the empirical works focused on developed countries and developing countries from GCC countries as oil-exporting countries. However, other MENA countries as oil-importing countries are ignored, and more specifically for Egypt, Morocco, and Jordan. Therefore, this study contributes to fill the gap of literature by investigating the dynamic relationship between oil prices and stock market returns in Egypt, Morocco, and Jordan as an oil-importing countries, in which they have a diversified welldeveloped stock market, and an open-economy that are affected by global oil price fluctuations. Moreover, it contributes to previous studies by examining weekly comprehensive and contemporary period from December 2005 to December 2018 to reach valid and consistent findings. The study was triggered in this period due to fluctuations in oil prices and several political events such as the Global Financial Crisis in 2007-2009, and the Arab uprising since the beginning of 2011 in which is called "The Arab Spring", and also the civil war in Libya since 2011. 


\section{DATA AND METHODOLOGY}

In order to investigate the dynamic relationship between oil prices and stock market returns of Egypt, Morocco, and Jordan; a highly frequency data (weekly data) was used over the period 2005-2018, in which this period witnessed high oil price fluctuations and global conflict. We collect closing stock market prices, oil prices, the Vix index and the weekly US treasury yields from the Bloomberg database.

Table no. 1 describes the equity indices we employ in our study.

Table no. 1 - The Study Sample

\begin{tabular}{ll}
\hline Index & Market Stock \\
\hline ASE Index & Amman Stock Exchange (Jordan) \\
\hline ExSM Index & Egyptian Stock Exchanges \\
\hline MCS Index & Morocco Stock Exchange \\
\hline
\end{tabular}

A class of suitable econometric models for accomplishing that task comprises Vector Autoregressive (VAR) models or Vector Error Correction Models (VECM). The choice between the two depends on the specific features of time series, i.e. whether or not they are stationary (Sims, 1980). Therefore, the study employed Augmented Dickey-Fuller test to check whether the study variables are stationery or non-stationary (having a unit root). To be conservative, the study includes four lagged differences allowing eliminating serial correlation in the error term, and choosing a $1 \%$ critical value.

In all the cases, the null hypothesis will be rejected at $1 \%$ level of significance, which assumes the presence of a unit root, and thus the series is being stationary at the level I(0). Results are reported in Table no. 2.

Table no. 2 - Augmented Dickey Fuller (ADF) Test

\begin{tabular}{lccc}
\hline & Jordan Market & Egypt Market & Morocco Market \\
\hline Test Statistic & -20.436 & -16.243 & -12.467 \\
\hline $1 \%$ Critical value & $-3.430(* * *)$ & $-3.430(* * *)$ & $-3.430(* *)$ \\
\hline
\end{tabular}

Therefore, VAR model is more appropriate than VECM model, in a nutshell, a VAR model is allowed to fit the joint dynamic behaviour of a set of variables, i.e. time series of stock market returns in the present study. In a nutshell, a VAR model is allowed to fit the joint dynamic behaviour of a set of variables, i.e. time series of stock market returns in the present study. It requires fitting a system of $m$ variables each of which is modelled as a linear function of $\mathrm{p}$ lags of itself and the other m-1 variables plus the error term. With reference to the variables in our study, the VAR model comprises the following four equations:

$$
\begin{aligned}
& S R_{t}=\alpha+\beta_{1} S R_{t-1}+\cdots+\beta_{p} S R_{t-p}+\gamma_{1} O I L_{t-1}+\cdots+\gamma_{p} O I L_{t-p}+\delta_{1} V I X_{t-1}+\cdots+\delta_{p} V I X_{t-p} \\
& +\theta_{1} \text { TREAS }_{t-1}+\cdots+\theta_{p} \operatorname{TREAS}_{t-p}+\varepsilon_{t} \\
& O I L_{t}=\alpha+\beta_{1} S R_{t-1}+\cdots+\beta_{p} S R_{t-p}+\gamma_{1} O I L_{t-1}+\cdots+\gamma_{p} O I L_{t-p}+\delta_{1} V I X_{t-1}+\cdots+\delta_{p} V I X_{t-p} \\
& +\theta_{1} T_{R E A S_{t-1}}+\cdots+\theta_{p} \operatorname{TREAS}_{t-p}+\vartheta_{t}
\end{aligned}
$$




$$
\begin{gathered}
V I X_{t}=\alpha+\beta_{1} S R_{t-1}+\cdots+\beta_{p} S R_{t-p}+\gamma_{1} \text { OIL }_{t-1}+\cdots+\gamma_{p} \text { OIL }_{t-p}+\delta_{1} V I X_{t-1}+\cdots+\delta_{p} V I X_{t-p} \\
+\theta_{1} \operatorname{TREAS}_{t-1}+\cdots+\theta_{p} \operatorname{TREAS}_{t-p}+\mu_{t} \\
\text { TREAS }_{t}=\alpha+\beta_{1} S_{t-1}+\cdots+\beta_{p} S R_{t-p}+\gamma_{1} \text { OIL }_{t-1}+\cdots+\gamma_{p} \text { OIL }_{t-p}+\delta_{1} V_{t} I X_{t-1}+\cdots+\delta_{p} V I X_{t-p} \\
+\theta_{1} \operatorname{TREAS}_{t-1}+\cdots+\theta_{p} \operatorname{TREAS}_{t-p}+\omega_{t}
\end{gathered}
$$

Where $S R$ denotes log stock market returns and Oil denotes log oil returns. Therefore, Stock Market Returns are calculated as $S R_{t}=\ln \left(\frac{P t}{P t-1}\right)$ where $P t$ denotes the closing price of the stock market index, at time t, and $P t-1$ denotes for the closing price of the stock market index, at time t-1. In the same fashion, Oil Price Return is measured as $O i l_{t}=\ln \left(\frac{O t}{O t-1}\right)$. Ot denotes the COI closing price, at time $\mathrm{t}$, and $\mathrm{Ot}-1$ denotes for the COI closing price, at time $\mathrm{t}-1$.

Oil prices, the study used the Brent oil price index (COI), collected from Bloomberg database. Vix is the values of Vix index, and Tre is the yield of US treasury bills. $\varepsilon_{t}, \vartheta_{t}, \mu_{t}$, and $\omega_{t}$ denote the error term and $\mathrm{P}$ is the number of lags. Akaike's Information Criteria (AIC) is employed to determine the number of lags in VAR. Moreover, we introduce three dummy variables to test for the impact of the Global Financial Crisis (GF), Arab Spring (AS), and Civil war in Libya (CL).

It is to note that a VAR model does not contain current-period values on the right side of each equation. Error terms represent fractions of each variable that are not explained by past values, i.e. the unpredictable innovation in each variable.

A common diagnostic from a VAR model is a set Granger causality tests, thereafter, Granger causality tests are performed as follows:

$$
\left\{\begin{aligned}
S R_{t} & =\alpha+\sum_{i=1}^{p} \beta_{i} S R_{t-i}+\sum_{i=1}^{p} \gamma_{i} \text { Oil }_{t-i}+\sum_{i=1}^{p} \delta_{i} \text { Vix }_{t-i}+\sum_{i=1}^{p} \theta_{i} \text { Tre }_{t-i}+\varepsilon_{t} \\
O I L_{t} & =\alpha+\sum_{i=1}^{p} \beta_{i} S R_{t-i}+\sum_{i=1}^{p} \gamma_{i} O i l_{t-i}+\sum_{i=1}^{p} \delta_{i} \text { Vix }_{t-i}+\sum_{i=1}^{p} \theta_{i} \text { Tre }_{t-i}+\vartheta_{t} \\
\text { VIX }_{t} & =\alpha+\sum_{i=1}^{p} \beta_{i} S R_{t-i}+\sum_{i=1}^{p} \gamma_{i} O i l_{t-i}+\sum_{i=1}^{p} \delta_{i} V_{i x_{t-i}}+\sum_{i=1}^{p} \theta_{i} \operatorname{Tre}_{t-i}+\mu_{t} \\
\text { TREAS }_{t} & =\alpha+\sum_{i=1}^{p} \beta_{i} S R_{t-i}+\sum_{i=1}^{p} \gamma_{i} \text { Oil }_{t-i}+\sum_{i=1}^{p} \delta_{i} \text { Vix }_{t-i}+\sum_{i=1}^{p} \theta_{i} \operatorname{Tre}_{t-i}+\omega_{t}
\end{aligned}\right.
$$

The Granger causality tests help testing the existence of causalities between time series. In this regard, a variable is said to granger cause another when taking into account lagged values of the first helps improving the forecasts of the second (Granger, 1969). Give its properties, estimating a VAR model provides a suitable environment for forecasting, which is the precise aim of the study. In that, the study forecast future paths of each time series conditional on their histories. To do that the study, use the vargranger routine available from STATA package. The study report results for the granger causality test only. Estimations of the preceding VAR model are available upon request. 
After that, on basis of such forecast the study estimates a cumulative response function which allows estimating the permanent effect of a shock occurring in the so-called impulse variable on a response variable. Specifically, the study aims at investigating the response of stock returns to shocks occurring to oil prices, Vix index and US treasury bills. Therefore, the study focuses specifically on the first equation, that explains stock returns as a function of lagged values of stock returns themselves and the lagged values of Oil, Vix and Tre.

\section{EMPIRICAL RESULTS}

Table no. 3 presents descriptive statistics of the study variables, it is noticed that the Egypt stock market reports the highest weekly return with a median of $0.36 \%$, and also the highest volatility, as it is indicated from the standard deviation and the percentile $\left(5^{\text {th }}\right.$ and $95^{\text {th }}$, respectively) values. On the other hand, The Jordan stock market reports the worst returns with a negative median weekly return of $-0.01 \%$.

Table no. 3 - Descriptive Statistics.

\begin{tabular}{lccccccc}
\hline & Mean & Median & St. Dev & Min & Max & $\mathbf{5}^{\circ} \mathbf{P}$ & $\mathbf{9 5}^{\circ} \mathbf{P}$ \\
\hline Morocco Market & $0.13 \%$ & $0.08 \%$ & 0.019 & $-8.49 \%$ & $6.96 \%$ & $-2.67 \%$ & $3.31 \%$ \\
\hline Jordan Market & $0.05 \%$ & $-0.01 \%$ & 0.024 & $-10.09 \%$ & $11.61 \%$ & $-3.54 \%$ & $3.72 \%$ \\
\hline Egypt Market & $0.20 \%$ & $0.36 \%$ & 0.042 & $-32.57 \%$ & $14.53 \%$ & $-6.65 \%$ & $5.73 \%$ \\
\hline
\end{tabular}

In addition, Table no. 4 shows the stock markets performance measured by Sharpe ratio during the overall period, Arab spring period, and post-Arab spring. As it is indicated, on average all the stock markets under consideration returned negative Sharpe ratios over the sample period and both over the Arab Spring and post Arab Spring periods. Again, Egyptian stock market performed slightly better than the other markets showing a less negative Sharpe Ratio. Thus, the Egyptian stock market performed slightly the same during and post-Arab spring. However, Morocco and Jordan stock market performance were slightly better in postArab spring.

Table no. 4 - Stock Markets Performance (Sharpe Ratio \%).

\begin{tabular}{lccc}
\hline & Overall Period & Arab Spring & Post-Arab Spring \\
\hline Morocco Market & -1.560 & -1.391 & -1.217 \\
\hline Jordan Market & -1.256 & -1.005 & -0.941 \\
\hline Egypt Market & -0.684 & -0.582 & -0.552 \\
\hline
\end{tabular}

Tables no. 5, no. 6, and no. 7 show the estimation results of the three VAR models, in which the first column shows the basic model, while the other three columns introduce the dummy variables for crisis periods. The study reports result pertaining to the stock returns equation, i.e. that estimating the impact of the lagged oil prices, volatility index, and treasury yields on stock market returns; naturally we include the lagged values of the stock returns themselves. 
Table no. 5 - Amman Stock Exchange (ASE)

\begin{tabular}{|c|c|c|c|c|}
\hline Oil & & & & \\
\hline L1. & 0.029 & 0.029 & 0.030 & 0.029 \\
\hline L2. & $0.053 * * *$ & $0.053 * * *$ & $0.054 * * *$ & $0.053 * * *$ \\
\hline \multicolumn{5}{|l|}{ Vix } \\
\hline L1. & 0.005 & 0.005 & 0.004 & 0.005 \\
\hline L2. & $-0.014 * *$ & $-0.014 * *$ & $-0.014 * *$ & $-0.014 * *$ \\
\hline \multicolumn{5}{|l|}{ Tre } \\
\hline L1. & -2.804 & -2.809 & -2.843 & -2.936 \\
\hline L2. & $18.502 * * *$ & $18.496 * * *$ & $18.436 * * *$ & $18.372 * * *$ \\
\hline \multicolumn{5}{|l|}{$S R_{t-1}$} \\
\hline L1. & -0.005 & -0.005 & -0.005 & -0.005 \\
\hline L2. & -0.051 & -0.051 & -0.051 & -0.051 \\
\hline AS & & 0.000 & & \\
\hline$C L$ & & & 0.001 & \\
\hline$G F$ & & & & -0.001 \\
\hline Cons & 0.000 & 0.000 & 0.000 & 0.000 \\
\hline
\end{tabular}

Note: This table reports the results of VAR test, in which the lag selection routine suggest using 2 lags. Oil is oil return, Vix is the value of Vix index, and Tre is the yield of US treasury bills, $\mathrm{SR}_{\mathrm{t}-1}$ is the lagged value of stock market return, As is the Arab Spring, GF is the Global Financial Crisis, and CL is the Civil war in Libya.

Table no. 6 - Egyptian Stock Market (ExSM)

\begin{tabular}{|c|c|c|c|c|}
\hline Oil & & & & \\
\hline L1. & $0.108 * * *$ & $0.108 * * *$ & $0.107 * * *$ & $0.109 * * *$ \\
\hline L2. & 0.043 & 0.043 & 0.043 & 0.044 \\
\hline \multicolumn{5}{|l|}{$V i x$} \\
\hline L1. & $-0.042 * * *$ & $-0.042 * * *$ & $-0.042 * * *$ & $-0.042 * * *$ \\
\hline L2. & $-0.066 * * *$ & $-0.066 * * *$ & $-0.065 * * *$ & $-0.066 * * *$ \\
\hline \multicolumn{5}{|l|}{ Tre } \\
\hline L1. & 5.817 & 5.746 & 6.028 & 5.485 \\
\hline L2. & 0.601 & 0.504 & 0.839 & 0.263 \\
\hline$S R_{t-1}$ & -0.041 & -0.042 & -0.042 & -0.042 \\
\hline L1. & -0.034 & -0.034 & -0.035 & -0.034 \\
\hline L2. & 0.108 & 0.108 & 0.107 & 0.109 \\
\hline$A s$ & & -0.002 & & \\
\hline$C L$ & & & -0.002 & \\
\hline$G F$ & & & & -0.003 \\
\hline Cons & 0.002 & 0.002 & 0.002 & 0003 \\
\hline
\end{tabular}

Note: This table reports the results of VAR test, in which the lag selection routine suggest using 2 lags. Oil is oil return, Vix is the value of Vix index, and Tre is the yield of US treasury bills, $\mathrm{SR}_{\mathrm{t}-1}$ is the lagged value of stock market return, As is the Arab Spring, GF is the Global Financial Crisis, and CL is the Civil war in Libya. 
Table no. 7 - Moroccan Stock Market (MCS).

\begin{tabular}{|c|c|c|c|c|}
\hline Oil & & & & \\
\hline L1. & -0.002 & -0.002 & -0.003 & -0.002 \\
\hline L2. & 0.021 & 0.021 & 0.021 & 0.022 \\
\hline L3. & $0.039 * *$ & $0.040 * *$ & $0.039 * *$ & $0.040 * *$ \\
\hline \multicolumn{5}{|l|}{ Vix } \\
\hline L1. & -0.007 & -0.008 & -0.007 & -0.008 \\
\hline L2. & -0.003 & -0.003 & -0.003 & -0.003 \\
\hline L3. & -0.004 & -0.004 & -0.004 & -0.004 \\
\hline \multicolumn{5}{|l|}{ Tre } \\
\hline L1. & 4.815 & 4.773 & 4.851 & 4.659 \\
\hline L2. & 5.233 & 5.199 & 5.280 & 5.086 \\
\hline L3. & 6.367 & 6.315 & 6.403 & 6.235 \\
\hline \multicolumn{5}{|l|}{ L4. } \\
\hline \multicolumn{5}{|l|}{$S R_{t-1}$} \\
\hline L1. & 0.051 & 0.045 & 0.051 & 0.050 \\
\hline L2. & 0.053 & 0.048 & 0.053 & 0.052 \\
\hline L3. & 0.038 & 0.032 & 0.037 & 0.036 \\
\hline As & & $-0.004 * *$ & & \\
\hline$C L$ & & & -0.001 & \\
\hline$G F$ & & & & -0.002 \\
\hline Cons & 0.001 & 0.002 & 0.001 & 0.001 \\
\hline
\end{tabular}

Note: This table reports the results of VAR test, in which the lag selection routine suggest using 3 lags. Oil is oil return, Vix is the value of Vix index, and Tre is the yield of US treasury bills, $\mathrm{SR}_{\mathrm{t}-1}$ is the lagged value of stock market return, As is the Arab Spring, GF is the Global Financial Crisis, and CL is the Civil war in Libya.

Looking at the effect of oil prices, we observe a positive impact of lagged prices on stock returns across all the three markets under observation. More precisely, we find a positive and statistically significant effect of the first lag for Egypt and the second lag for Jordan. In both cases significance is at $1 \%$ level. In the case of the Morocco stock market the third lag is significant at $5 \%$ level. By contrast, our results account for a negative volatility-stock returns relation for Jordan and Egypt. The Vix, actually, enter the relationship with stock returns with a negative sign and a $1 \%$ significance level for Jordan (second lag) and a $1 \%$ significance level for Egypt (both first and second lag). These results are consistent with the results of Sarwar (2012), who documented a significant negative relationship between Vix and stock market return in China and Brazil. The Vix does not show a statistically significant relationship with stock returns in the case of Morocco. Treasury yields show a statistically significant (and positive) relationship with returns in Jordan only. Lagged values of stock returns are not significant in all the three markets. Crisis dummies do not have a significant impact on returns, except for Morocco where the Arab Spring turns out to have a negative and statistically significant (5\%) relationship with returns.

The results indicate short-run estimates, where it documents a statistically positive shortterm relationship at $1 \%$ and $5 \%$ confidence between oil price and stock market returns in Egypt, Jordan, and Morocco respectively. While the sign of the relationship between stock market volatility and stock returns is quite expected, the most challenging result pertain the oil price-stock return relation. It might turn out quite surprising the positive impact of oil price 
dynamics on returns. Specifically, or results differ to a certain extent form other studies that investigate the same relationship. For instance, Al-Qudah (2014) documented a negative significant relationship between oil price shocks and stock market returns, and found no directional causality from oil price shocks to stock returns, over the period 2000-2014 using monthly data from ASE. On the other hand, these results are consistent with the results of Zaki et al. (2016) who found out a positive relationship between oil price and stock market return in Egypt over the period 1999-2015.

However, the nature of that relationship is quite a complex one depending on a variety of factors, above all macroeconomic factors and openness to trade. Actually, looking at the prevailing literature the issue of the effects of oil and energy is not so obvious with evidences being quite mixed. A body of literature investigates the causal relationship between energy consumption, $\mathrm{CO} 2$ emissions and economic growth in MENA countries (e.g., Gorus and Aslan, 2019; Al-Mulali and Binti Che Sab, 2012). Based on 58 countries, Saidi and Hammami (2015) accounted for a positive relationship of economic growth and energy consumption in different panels comprising a Global Panel, Europe and Asia, the Latin American region along with the Middle Eastern, North Africa and Sub-Saharian region. Moreover, they found a positive and significant association of financial development with energy consumption. Similarly, Muhammad (2019) employs a SUR model to jointly investigate the mutual relationships between growth, energy consumption and emissions. In particular, their results point to a positive impact of energy consumption on economic growth in developed and emerging economies and a negative one in MENA countries. In our view, the widely accounted direct relationship between the growth ad stock market performance help support our results.

The countries in our sample witnessed, starting from 2005, gasoline consumptions rising at a compound annual growth rate of 5.9\% (Jordan), 7.5\% (Egypt) and 5.6\% in barrels per day. Indeed, it could be expected oil price shocks driven by improved expectations on future economic activity being actually associated with rising stock prices (and reduced volatility) rather than capital market downturns. The latter would be much more an effect of a negative scarcity shock.

The magnitude of the effect in the Egyptian stock market is economically stronger than in Jordan and Morocco stock market. It is also noted that there is a longer lasting effect in the Moroccan stock market; since the returns in the Egyptian stock market are affected by the first lag of the Oil price returns while Jordan and Morocco are sensitive to the second and third lag, respectively.

To provide a better insight into the relationships linking macroeconomic variables and stock markets the study performs a standard granger casualty test on basis the of our VAR results. Table no. 8 depicts the results. The study finds that Oil prices granger cause stock market returns in all countries in our sample. The other global and financial variables show a quite different behaviour. The Vix index shows a causal relationship to stock returns in Jordan and Egypt but not in Morocco. Treasury yields by contrast granger cause stock returns in Jordan and Morocco but not in Egypt. Also, the study tested for the round way causality finding no evidence that stock market prices in the countries under consideration affect global variables. Those results are not reported, however they are available upon request. 
Table no. 8 - Granger causality test

\begin{tabular}{lccc}
\hline & Jordan Stock Market & Egypt Stock Market & Morocco Stock Market \\
\hline Oil & $8.702^{* *}$ & $10.371^{* * *}$ & $7.514^{*}$ \\
\hline Vix & $6.682^{* *}$ & $47.683^{* * *}$ & 2.998 \\
\hline Treasury & $12.072^{* * *}$ & 0.476 & $7.122^{*}$ \\
\hline ALL & $28.774 * * *$ & $66.539 * * *$ & $18.518^{* *}$ \\
\hline
\end{tabular}

Based on VAR estimates the study, then, test the impulse response functions, i.e. the study ascertain the reaction of a response variable to shocks occurring in the so-called impulse variable. In the analysis, response variables are represented by stock market returns in the countries in the sample while the impulse variables are Oil prices, the Vix Index and the treasury yields respectively. Figure no. 1 depicts the results.

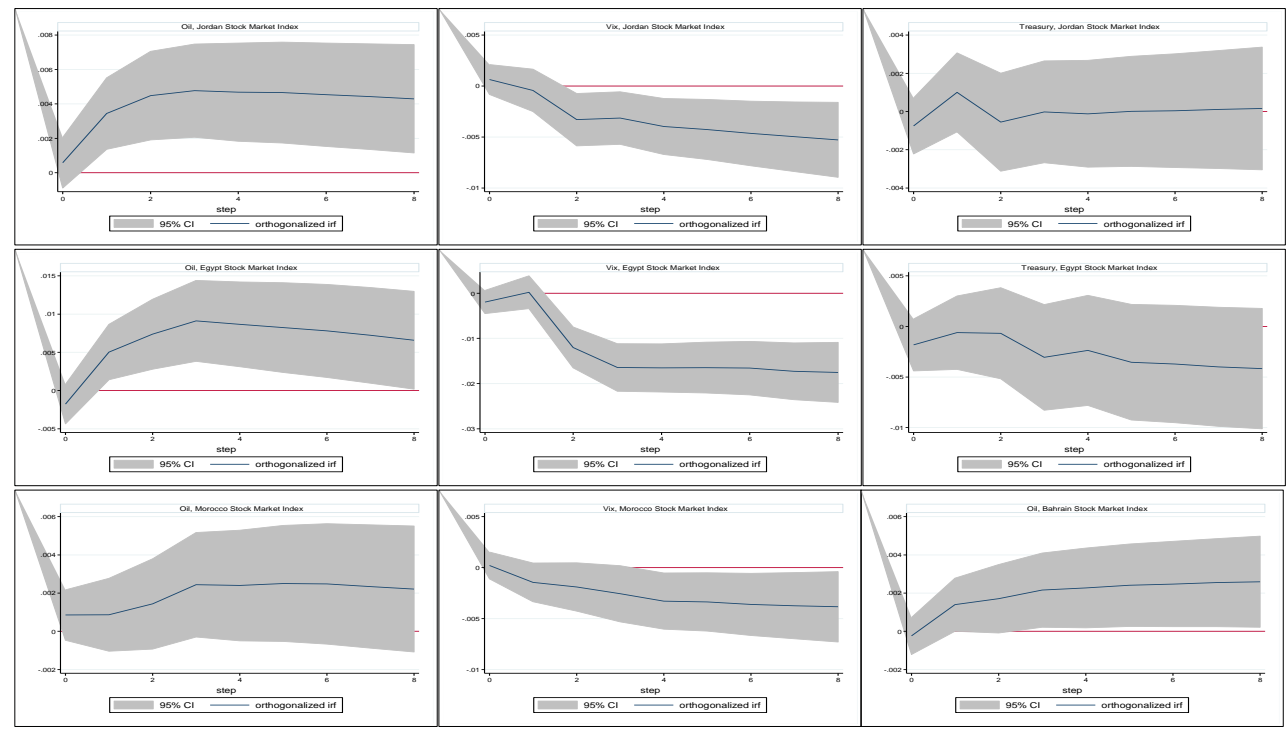

Figure no. 1 - Impulse Response Functions

The picture on the left-hand side of the figure represents the responses of each stock market to Oil price shocks while pictures in the middle are referred to responses to the Vix index. The right-hand of the panel, finally, depicts responses to treasury yields.

Results are a quite contrasting when looking across markets. Starting with Oil prices, a shock occurring in the Oil market produces different responses in stock markets. Egypt shows a negative impact in stock prices in the very short term while recovering immediately after the shock. Egypt stock market prices, however, revert down after peaking. Interestingly, Jordan and Morocco show different patterns. Both show a positive reaction after a shock occurring in the Oil market. However, while Jordan shows a spike in the very short run before flattening, movements in the Morocco stock market are much more subdued.

Looking at responses to shocks in the Vix index, the study observes a negligible impact in magnitude (positive in Morocco and Jordan, negative in Egypt) across all stock market in the sample immediately after the shock followed by a downturn in stock markets although 
with different patterns. Jordan, after falling in the very short term tends to stabilize. Reaction in Egypt is quite different. While showing an upward although negligible reaction in the very short term, the market then drops before flattening. Morocco, finally, shows a more subdued downward reaction before flattening.

Finally, different responses to shock in the treasury yields as well. Jordan and Egypt show a negative reaction to a shock in yields. Jordan recovers in the following periods with the effect of a shock in yields on the Jordanian stock market subsequently fading away. The opposite is the movement in Egypt, where after a contained rebound after the shock, the downturn movement continues. Finally, in Morocco there is no reaction to shock in treasury yields in the very short term.

\section{CONCLUSIONS AND RECOMMENDATIONS}

This study examines the dynamic relationship between oil price shocks and stock market returns in Egypt, Morocco, and Jordan as oil-importing countries in the MENA region, in which they have a diversified well-developed stock market, and an open-economy that are affected by global oil price fluctuations. The study used weekly data over the period from December 2005 to December 2018. Oil price shocks are caused by political and economic conflicts, Global Financial Crisis, Arab Spring, and the civil war in Libya. The Vector Auto Regression results concluded that oil prices have a positive impact on stock returns on the three markets under consideration while stock market volatility shows an inverse effect. Impulse response functions are run as well. Shocks occurring in Oil prices produce different responses in stock markets with Egypt experiencing a negative impact in stock returns over the very short run and, then, recovering while Jordan stock market spikes before flattening. Response in Morocco is much more subdued. Differences persist also in responses of stock returns to volatility shocks. Results are consistent with previous findings. The results for Egypt, Morocco, and Jordan during the period 2005-2018, showed a quite clear upward trend in gasoline consumptions. It might be well that stock returns embody expectations of improved economic activity. Another plausible explanation is the correlation of these markets with oil exporting countries i.e. GCC countries which is a good argument for a positive relationship between oil prices and stock returns.

These findings have important implications for policy makers, were they should pay attention to the oil price when monitoring and planning investment activities. Moreover, these findings also have important implications for academics, domestic and international investor, and investment manager.

Oil price shocks may have in each country different specific causes and variables, and given that these findings only explain the dynamic relationship between oil price shocks and stock market returns in Egypt, Morocco, and Jordan, therefore these findings cannot explain all stock markets. Further and future research in this domain is recommended. Moreover, although the general stock market return is important to be investigated, however including sectorial stock market return could have been more exploratory, and investigating other countries especially in MENA countries is recommended.

\section{ORCID}

Demeh Daradkah iD http://orcid.org/0000-0002-1807-5196

Josanco Floreani iD http://orcid.org/0000-0001-9474-1245

Stefano Miani (D) http://orcid.org/0000-0003-2321-8312 


\section{References}

Abdelsalam, M. A. M., 2020. Oil price fluctuations and economic growth: the case of MENA countries. Review of Economics and Political Science, ahead-of-print(ahead-of-print). http://dx.doi.org/10.1108/REPS-12-2019-0162

Abdulkarim, F. M., Akinlaso, M. I., Hamid, B. A., and Ali, H. S., 2020. The nexus between oil price and islamic stock markets in Africa: A wavelet and Multivariate-GARCH approach. Borsa Istanbul Review, 20(2), 108-120. http://dx.doi.org/10.1016/j.bir.2019.11.001

Ajmi, A. N., El-montasser, G., Hammoudeh, S., and Nguyen, D. K., 2014. Oil prices and MENA stock markets: new evidence from nonlinear and asymmetric causalities during and after the crisis period. Applied Economics, 46(18), 2167-2177. http://dx.doi.org/10.1080/00036846.2014.896987

Al-Fayoumi, A. N., 2009. Oil Prices and Stock Market Returns in Oil Importing Countries: The Case of Turkey, Tunisia and Jordan. European. Journal of Economics, Finance and Administrative Science, $16,86-101$.

Al-Hajj, E., Al-Mulali, U., and Solarin, S. A., 2018. Oil Price Shocks and Stock Returns Nexus for Malaysia: Fresh Evidence from nonlinear ARDL test. Energy Reports, 4(November), 624-637. http://dx.doi.org/10.1016/j.egyr.2018.10.002

Al-Mulali, U., and Binti Che Sab, C. N., 2012. The Impact of Energy Consumption and CO2 Emission on the Economic Growth and Financial Development in the Sub Saharan African Countries. Energy, 39(1), 180-186. http://dx.doi.org/10.1016/j.energy.2012.01.032

Al-Qudah, A., 2014. The Impact of Oil Price Shocks on Amman stock Exchange Real Returns. International Journal of Business and Social Science, 5(12), 224-235.

Arouri, M., Lahiani, A., and Nguyen, K. D., 2011. Return and Volatility Transmission between World Oil Prices and Stock Markets of the GCC Countries. Economic Modelling, 28, 1815-1825.

Arouri, M. E. H., and Rault, C., 2012. Oil Prices and Stock Markets in GCC Countries: Empirical Evidence from Panel Analysis. International Journal of Finance \& Economics, 17(3), 242-253.

Bjørnland, H. C., 2009. Oil Price Shocks and Stock Market Booms in an Oil exporting Country. Scottish Journal of Political Economy, 56(2), 232-254. http://dx.doi.org/10.1111/j.1467-9485.2009.00482.x

Bouri, E., Awartani, B., and Maghyereh, A., 2016. Crude Oil prices and Sectoral Stock Returns in Jordan around the Arab uprisings of 2010. Energy Economics, 56(May), 205-214. http://dx.doi.org/10.1016/j.eneco.2016.03.021

British Petroleum, 2019. Energy with Purpose. BP Annual Report and Form, 20-F, 2019.

Brown, S. J., Otsuki, T., Elton, E. J., and Gruber, M., 1990. Macroeconomic Factors and the Japanese Equity Markets: The CAPMD project. In E. J. Elton and M. Gruber (Eds.), Japanese Capital Markets. New York: Harper and Row.

Burbidge, J., and Harrison, A., 1984. Testing for the Effects of Oil-Price Rises Using Vector Autoregressions. International Economic Review, 25(2), 459-484. http://dx.doi.org/10.2307/2526209

Chen, N. F., Roll, R., and Ross, S. A., 1986. Economic Forces and the Stock Market. The Journal of Business, 59(3), 383-403. http://dx.doi.org/10.1086/296344

Chen, S. S., 2010. Do Higher Oil Prices Push the Stock Market into Bear Territory? Energy Economics, 32(2), 490-495. http://dx.doi.org/10.1016/j.eneco.2009.08.018

Cong, R. G., Wei, Y. M., Jiao, J. L., and Fan, Y., 2008. Relationships between Oil Price Shocks and Stock Market: An Empirical Analysis from China. Energy Policy, 36(9), 3544-3553. http://dx.doi.org/10.1016/j.enpol.2008.06.006

Ferson, W. E., and Harvey, C. R., 1995. Predictability and Time-varying Risk in World Equity Markets. Research in Finance, 13, 25-88.

Filis, G., 2010. Macro Economy, Stock Market and Oil Prices: Do Meaningful Relationships Exist among their Cyclical Fluctuations? Energy Economics, 32(4), 877-886. http://dx.doi.org/10.1016/j.eneco.2010.03.010 
Gisser, M., and Goodwin, T. H., 1986. Crude Oil and the Macroeconomy: Tests of Some Popular Notions: Note. Journal of Money, Credit and Banking, 18(1), 95-103. http://dx.doi.org/10.2307/1992323

Gorus, M. S., and Aslan, M., 2019. Impacts of Economic Indicators on Environmental Degradation: Evidence from MENA Countries. Renewable \& Sustainable Energy Reviews, 103(April), 259-268. http://dx.doi.org/10.1016/j.rser.2018.12.042

Granger, C. W., 1969. Investigating Causal Relations by Econometric Models and Cross-Spectral Methods. Econometrica, 37(3), 424-438. http://dx.doi.org/10.2307/1912791

Hamao, Y., 1988. An Empirical Examination of Arbitrage Pricing Theory: Using Japanese data. Japan and the World Economy, 1(1), 45-61. http://dx.doi.org/10.1016/0922-1425(88)90005-9

Hamilton, D. J., 1983. Oil and the macroeconomy since World War II. Journal of Political Economy, 91(2), 228-248. http://dx.doi.org/10.1086/261140

Hamilton, D. J., and James, D. H., 2009. Causes and Consequences of the Oil Shock 2007-2009. Brookings Papers on Economic Activity, 2009(1), 215-261. http://dx.doi.org/10.1353/eca.0.0047

Huang, D. R., Masulis, R. W., and Stoll, H., 1996. Energy Shocks and Financial Markets. Journal of Futures Markets, 16(1), 1-27. http://dx.doi.org/10.1002/(SICI)1096-9934(199602)16:13.0.CO;2-Q

International Institute for Labour StudIes, 2013. Executive summary - World of Work Report 2013: Repairing the economic and social fabric. World of Work Report, 2013(1), i-4. http://dx.doi.org/10.1002/wow3.33

International Monetary Fund, 2011. International Monetary Fund Annual Report 2011. Pursuing Equitable and Balanced Growth. http://dx.doi.org/10.5089/9781616351120.011

Jammazi, R., and Aloui, C., 2010. Wavelet Decomposition and Regime shifts: Assessing the effects of crude oil shocks on stock market returns. Energy Policy, 38(3), 1415-1435. http://dx.doi.org/10.1016/j.enpol.2009.11.023

Jiménez-Rodríguez, R., and Sanchez, M., 2005. Oil Price Shocks and Real GDP Growth: Empirical Evidence for Some OECD Countries. Applied Economics, 37(2), 201-228. http://dx.doi.org/10.1080/0003684042000281561

Jones, C. M., and Kaul, G., 1996. Oil and Stock Markets. The Journal of Finance, 51(2), 463-491. http://dx.doi.org/10.1111/j.1540-6261.1996.tb02691.x

Kaneko, T., and Lee, B. S., 1995. Relative Importance of Economic Factors in the US and Japanese Stock Markets. Journal of the Japanese and International Economies, 9(3), 290-307. http://dx.doi.org/10.1006/jjie.1995.1015

Korhonen, I., and Ledyaeva, S., 2010. Trade Linkages and Macroeconomic Effects of the Price of Oil. Energy Economics, 32(4), 848-856. http://dx.doi.org/10.1016/j.eneco.2009.11.005

Lescaroux, F., and Mignon, V., 2008. On the Influence of Oil Prices on Economic Activity and other Macroeconomic and Financial Variables. OPEC Energy Review, 32(4), 343-380. http://dx.doi.org/10.1111/j.1753-0237.2009.00157.x

Maghyereh, M., and Al-Kandari, A., 2007. Oil Prices and Stock Markets in GCC Countries: New Evidence from non -linear Cointegration analysis. Managerial Finance, 33(7), 449-460. http://dx.doi.org/10.1108/03074350710753735

Mendoza, O., and Vera, D., 2010. The Asymmetric Effects of Oil Shocks on an Oil-Exporting Economy. Cuadernos de Economia (Santiago, Chile), 47(135), 3-13. http://dx.doi.org/10.4067/S071768212010000100001

Miller, J. I., and Ratti, R. A., 2009. Crude Oil and Stock Markets: Stability, Instability, and Bubbles. Energy Economics, 31(4), 559-568. http://dx.doi.org/10.1016/j.eneco.2009.01.009

Mohanty, S. K., Nandha, M., Turkistani, A. Q., and Alaitani, M. Y., 2011. Oil Price Movements and Stock Market Returns: Evidence from Gulf Cooperation Council (GCC) countries. Global Finance Journal, 22(1), 42-55. http://dx.doi.org/10.1016/j.gfj.2011.05.004

Mokni, K., 2020. Time-Varying Effect of Oil Price Shocks on the Stock Market Returns: Evidence from Oil Importing and Oil-Exporting Countries. Energy Reports, 6(November), 605-619. http://dx.doi.org/10.1016/j.egyr.2020.03.002 
Muhammad, B., 2019. Energy Consumption, CO2 Emissions and Economic Growth in Developed, Emerging and Middle East and North Africa Countries. Energy, 179, 232-245.

Nandha, M., and Faff, R., 2008. Does Oil Move Equity Prices? A Global View. Energy Economics, 30(3), 986-997. http://dx.doi.org/10.1016/j.eneco.2007.09.003

O'Neill, J. T., Penm, J., and Terrell, D. R., 2008. The Role of Higher Oil Prices: A Case of Major Developed Countries. Research in Finance, 24, 287-299. http://dx.doi.org/10.1016/S0196-3821(07)00211-0

OECD, 2006. MENA-OECD Investment Program National Investment Reform Agenda Workshop for the Hashemite Kingdom of Jordan. http://www.oecd.org/dataoecd/4/29/38148879.pdf.

Papapetrou, E., 2001. Oil Price Shocks, Stock Market, Economic Activity and Employment in Greece. Energy Economics, 23(5), 511-532. http://dx.doi.org/10.1016/S0140-9883(01)00078-0

Park, J., and Ratti, R. A., 2008. Oil Prices and Stock Markets in the U.S. and 13 European Countries. Energy Economics, 30(5), 2587-2608. http://dx.doi.org/10.1016/j.eneco.2008.04.003

Sadorsky, P., 1999. Oil Price Shocks and Stock Market Activity. Energy Economics, 21(5), 449-469. http://dx.doi.org/10.1016/S0140-9883(99)00020-1

Saidi, K., and Hammami, S., 2015. The Impact of CO2 Emissions and Economic Growth on Energy Consumption in 58 Countries. Energy Reports, 1(November), 62-70. http://dx.doi.org/10.1016/j.egyr.2015.01.003

Sarwar, G., 2012. Is VIX an Investor Fear Gauge in BRIC Equity Markets? Journal of Multinational Financial Management, 22(3), 55-65. http://dx.doi.org/10.1016/j.mulfin.2012.01.003

Sims, C. A., 1980. Macroeconomics and Reality. Econometrica, 48(1), 1-48. http://dx.doi.org/10.2307/1912017

Venditti, F., and Veronese, G., 2020. Global Financial Markets and Oil Price Shocks in Real Time. European Central Bank, Working Paper Series, 2472. http://dx.doi.org/10.2139/ssrn.3577551

Wang, Y., Wu, C., and Yang, L., 2013. Oil Price Shocks and Stock Market Activities: Evidence from Oil Importing and Oil-Exporting Countries. Journal of Comparative Economics, 41(4), 1220-1239. http://dx.doi.org/10.1016/j.jce.2012.12.004

World Bank, 2018. Development Indicators. from http://datatopics.worldbank.org/world-developmentindicators/

Youssef, M., and Mokni, K., 2019. Do Crude Oil Prices Drive the Relationship between Stock Markets of Oil-Importing and Oil-Exporting Countries? Economies, 7(3), 70. http://dx.doi.org/10.3390/economies7030070

Zaki, F., Elgamma, M., and Hussainey, K., 2016. Macro Economy, Stock Market and Oil Prices Relationships before and after the Egyptian Revolution Era. Doha Institute for Graduate Studies. https://www.dohainstitute.edu.qa/MEEA2016/Downloads/Fatma\%20Zaki.pdf.

Zamereith Gourène, G. A., and Mendy, P., 2018. Oil prices and African Stock Markets Co-Movement: A Time and Frequency Analysis. Journal of African Trade, 5(1-2), 55-67. http://dx.doi.org/10.1016/j.joat.2018.03.002

Zarour, B. A., 2006. Wild Oil Prices, but Brave Stock Markets! The case of GCC Stock Markets. Operations Research, 6(2), 145-162. http://dx.doi.org/10.1007/BF02941229

\section{Copyright}

This article is an open access article distributed under the terms and conditions of the Creative Commons Attribution-NonCommercial-NoDerivatives 4.0 International License. 